\title{
TWO-PHASE PRICING AND ORDERING DECISIONS UNDER TRADE CREDIT
}

\author{
Tata Aransta Imas Puspita ${ }^{1)}$, Yu-Chung Tsao ${ }^{2)}$ Erma Suryani $^{3)}$ \\ 1,2 Department of Industrial Management, School of Management \\ National Taiwan University of Science and Technology \\ No.43, Sec. 4, Keelung Road, Da'an District, Taipei City 106, Taiwan (R.O.C) \\ Phone: +886-2-2737-6341, Fax: +886-2-2737-6344 \\ ${ }^{3}$ Information System, Faculty of Technology Information, Institut Sepuluh Nopember \\ Kampus ITS Sukolilo, Surabaya, 60111 \\ Telp : (031) 59942514, Fax : (031) 5923465 \\ E-mail: aransta@gmail.com ${ }^{1)}$
}

\begin{abstract}
Abstrak
Dalam penelitian ini, kami mempertimbangkan model persediaan terintegrasi dengan permintaan yang dipengaruhi oleh harga jual produk. Adapun jika terdapat permintaan selama persediaan tidak ada, retailer akan melakukan pemesanan ulang sebesar percentase tertentu dari jumlah permintaan yang terjadi. Ini menandakan bahwa ada sejumlah konsumen yang tetap memesan produk walaupun produk tersebut belum ada dan bersedia menunggu hingga pemesanan berikutnya untuk mendapatkan produk tersebut. Dalam hal ini, penundaan pembayaran oleh retailer terhadap supplier juga diperhatikan (trade credit). Ada tiga solusi model yang diusulkan dalam penelitian ini yang berdasarkan kriteria: waktu dimana persediaan tidak ada, rentang waktu penundaan pembayaran oleh retailer terhadap supplier, waktu terjadinya pemesanan berikutnya kepada supplier. Untuk mendapatkan profit yang maksimal, kami mengusulkan algoritma untuk menentukan harga jual produk yang optimal, rentang waktu terjadinya pemesanan sebelum dan setelahnya, dan percentase dari jumlah permintaan yang akan dipenuhi dari stok yang ada. Khususnya, dalam penelitian ini, kami mempertimbangkan dua fase pelabelan harga jual yang optimal, yaitu kita menentukan harga jual produk yang berbeda selama periode persediaan ada dan selama persediaan tidak ada. Kami menguji algoritma dengan memberikan data pada parameter model dan menganalisa pengaruh perubahan nilai pada parameter tersebut terhadap nilai solusi optimal dan profit yang didapatkan. Dari hasil yang didapatkan juga menunjukkan bahwa dua fase pelabelan harga jual yang berbeda adalah salah satu bentuk strategi pricing yang perlu diperhatikan karena dapat memperoleh profit yang lebih besar daripada satu fase pelabelan harga jual (harga jual produk selama periode persediaan ada dan selama persediaan tidak ada adalah sama).
\end{abstract}

\section{Abstract}

In this paper, we consider an integrated inventory model with a price sensitive demand rate, where the demand during the out-of-stock period is partially backordered. Also, a trade credit period is provided from supplier to retailer. By analyzing the total net profit function, we present an algorithm to determine the optimal selling price, the length of replenishment cycle, and demand's percentage that will be filled from stock. Specially, we consider two-phases pricing, it means that we determine the optimal selling price for in-stock period and optimal selling price for out-stock period. A numerical study is used to illustrate the solution procedure and to discuss the company behavior with different parameter values. The result also explains that two-phases pricing strategy is supreme to one-phase pricing strategy while obtaining the maximum profit.

Key words: Partial Backordering, Trade Credit, Pricing, Ordering

\section{INTRODUCTION}

Talking about managing inventory, it does not seem like a mundane speculation. The enterprises need to recognize this duty as a substantial part of a company's business strategy because an inventory often causes the highest expense and vice versa. In management of inventory concern, there is knowledge that help retailers on how to manage the inventory in order to avoid these problems above. Hence, we discuss about "inventory management", it has phenomena related to "how many units to order" and "when to order". These phenomena has aim to make sure inventories of goods available for customers. 
There are several methods that can be adopted to assist in inventory management decision making. One of the assumptions in the classical economic order quantity (EOQ) model, stockouts is not allowed. This means that the total amount of ordered items is exactly sufficient to meet demand in time. However, there are many things known uncertainty. Though retailers try to avoid stock-outs, the possibility of their occurring always exists. There is a fraction of demand will be backordered for the customers who have patient to wait for delivery, the demand is satisfied by black-logged items; others are not will to wait, their demands unsatisfied and that is claimed as lost sale case (Sana, 2010).

Furthermore, the classical economic order quantity (EOQ) model assumes that retailers must pay for the purchased items as soon as these items are received. In practice, this is not always happen. To encourage the retailer to buy more items, the supplier offers the retailer a delay in paying for an order. The term is trade credit period. Meanwhile, a new approach used in which there are different prices for in-stock and stock-out period, it can be happen when shortage is allowed by retailer. Regarding to satisfy a customer's waiting time the retailers offer a low price during stock-out periods. This research is determining the optimal selling price for instock and out-stock period. In conducting this study, we have the same assumptions in (Tsao, 2010), including that partial backorder is permitted and delay payment is offered by supplier. In addition, we assumed that the demand rate is price dependent.

The main objective is developing an infinite horizon inventory model for single item under trade credit and partial backorder. The second objective is obtaining the maximize profit as an objective function under these circumstances while determining the optimal value of decision variables. They are: (1) optimal replenishment cycles as denoted by $T$, (2) optimal demand's percentage that will be filled from stock as denoted by $F$, (3) optimal selling price for instock period as denoted by $p_{1}$, (4) optimal selling price for out-stock period as denoted by $p_{2}$.

The work of this research is presented and arranged into five chapters. In Section 1, we present the domain of this research. In Section 2 , we explain the literature studies of this research by analyzing the previous paper. In Section 3, we develop the notation and assumptions used throughout this study. Then, the mathematical models are also derived in order to maximize the total profit. Numerical study is defi- ned in Section 4 to prove the applicability of the developed model. In addition, we characterize the effect of the parameter's value on the optimal price in both of period, replenishment cycle, order quantity, and total profit. In Section 5, we explain the conclusions of this research and possible future work.

\section{METHODOLOGY}

\subsection{Trade Credit}

The first key component of this model is trade credit. During credit period, there is no charge in any interest from the retailer on the outstanding amount. So that the retailer can sell te items while accumulating revenue and earning the interest. Beyond this period, a higher interest will be charged if the payment is not settled. Goyal (1985) First developed an EOQ model under the conditions of permissible delay in payments. Jaggi (1994) extended Goyal's model for deteriorating items. He used the discounted cash-flows (DCF) approach for obtaining optimum order quantity in the existence of trade credit. Chung (2011) developed a simple algorithm to overcome shortcomings in Jaggi and Aggarwal's model. In their result, they obtained the optimal solution that determining the optimal cycle time is better than the previous one. For compatibility purposes, Jamal (1997) determined an optimal ordering policy for deteriorating items under permissible delay of payment and allowable shortage. Chung (2009) explored the new model inventory that more complete than Jamal's model. They showed the total annual variable cost as objection function possesses some kinds of convexities. Taleizadeh (2013) modeled different consideration to the payment. There is a fraction of the purchasing must be paid at the beginning of the period and the remaining amount can be paid later. It called partial delayed payment. They also permitted shortages that happen as combination of backorder and lost sales. In other hand, considering the effects to inflation and time value of money, Taleizadeh (2013) proposed an inventory model to handle the deteriorating items when shortage is permitted and supplier offers delayed payment. This model aims to derive the optimal order, how many shortage quantities, and the number of replenishment under which the total cost is minimized.

Chang (2006) regard that the delay in payments depends on the quantity ordered. The fixed trade credit period is permitted when the order quantity is greater than the quantity at which the delay payment is permitted. Otherwise, the retailer must make a payment for the item immediately. Huang (2007) has a different treatment, he of- 
Puspita, dkk., Two-Phase Pricing and Ordering Decisions under Trade Credit

fers the retailer partially permissible delay in payment when the order quantity is smaller than a predetermined quantity. It implies that there are some portions of trade credit that must be paid by retailer when the order is received. Then, at the end of permissible delay, the retailer must pay off the remaining balances.

\subsection{Partial Backordering}

The second key component of the model that we propose here is partial backordering of demand during shortage period. Park (1982) presented an inventory model in which there is a constant fraction of the demand is back-ordered, and the remaining function is lost. Vijayan (2008) developed a mixture of back-orders and lost sales, as Park's model, but they apply fuzziness in the cost parameter to know the impact and sensitiveness of impreciseness of cost component in the decision variable and total cost. In order to obtain the optimal policy for the partial backordering deterministic EOQ problem, Pentico (2009) start to identify the minimum value of, the fraction of stock-out that will be backordered, for which stock-out should be allowed and if is greater than this minimum value, then they determine the optimal order quantity. As in (Pentico, 2009; Taleizadeh, 2012) also used the same assumption, that is the percentage of shortages that will be backordered is constant over time. But, they had an additional condition should be concerned, their research considered a special sale prices that offered by supplier to encourage sale or decrease inventories of certain items.

Different from the most researchers, Hu (2009) proposed an inventory model with partial backlogging in which the backorder cost per unit time is linearly increasing function of shortage time instead of being a constant. Regarding to when delivery will take place, Toews (2011) assumed that the backordering percentage would increase as the time at which the replenishment order is placed. If the time to delivery gets shorter the value of $\beta$, the backordering percentage, will increases. In other hand, Wang (2002) had the different assumption, the longer the waiting time for the next replenishment causes the backlogging rate will be smaller. It is reasonable for many products with growing sales because the waiting time for the next replenishment is the main factor whether the customers will be able to wait or cancel their demands. It could be assumed that the backlogging rate is expected to be time-dependent.

\subsection{Pricing Policy}

The third key component of our model is considering selling price as a decision variable. Abad (2001) determined the pricing and lot sizing for infinite horizon. However, they omit the backorder cost and the lost sale cost since these costs not simple to assess in practice. Abad (2008) extended his previous model, he include all three costs; the backorder cost, the lost sale cost, and the shortage cost in this research to obtain the optimal price and lot size. Considering situations where there are customers with reservations may cancel advance orders and demand depends on price, You, (2006) investigated an inventory model to determine the order quantity and selling prices. Banerjee (2010) raised different case for the situation when many commodities have a seasonal demand pattern. In such situation, demand rate depends upon both price and time and backlog of shortages is time dependent. Then, they generated a solution to get the maximal net profit under an optimal procurement and pricing. Teng (2005) assumed the selling price is necessarily higher than the purchase cost, he developed a model for retailer to determine its optimal price and lot size simultaneously when there is a permissible delay in payments.

Chang (2009) examined the order-size dependent trade credit, where demand rate is a decreasing function of retail price. They provided an iterative algorithm to find the retail price, buyer's order quantity, and the numbers of shipment per production run from the vendor to the buyer. Regarding partial backlogging and lost sales, Sana (2010) developed a model to obtain the optimal solution for the replenishment schedule, in which selling price is a decision variable. In addition, the demand rate is price dependent and the deterioration rate is taken to be time proportional. By assuming that the demand rate is a linearly decreasing function of price and decreases exponentially with time, Tsao, (2010) developed this new approach model where regarding to the two-phases pricing. Its objective is determining the optimal price instock period and stock-out period, replenishment, and service level policy for deteriorating and fashion goods under trade credit and partial backlogging conditions.

\subsection{Price Dependent Demand}

In many realistic situations, a firm is generally able to influence the demand rate by manipulating their prices. It has objective to increase the sales of product and maximize the profit. In fact, if the selling price increases, the demand rate will be decreased. Under such conditions, 
the demand rate should be handled as a decision variable, since it cannot be controlled by the firm, but the demand rate is influenced by selling price. Wee (1999) assumed that the demand rate is decrease as price for the product increases. In his study, he focuses to maximize profit. You (2006) pointed out a service inventory control problem in which a firm orders and sells service on a specific future date. In his model, he also considered product demand is price dependent in which the selling price is a decision variable. For perishable item, Sana (2010) developed an EOQ model over infinite time horizon. He also suggested that demand is pricedependent.

\section{RESULT and EXPLANATION}

The mathematical model in this work can be developed by considering the following assumptions:

1. The inventory system regards only one item over a known and infinite time horizon.

2. Replenishments occur instantaneously.

3. Demand rate for item depends on the selling price, and that the relation between demand and price is linear and given by

$$
D\left(p_{i}\right)=a_{0}-b_{0} p_{i}
$$

4. Shortages are allowed.

5. The purchasing cost to supplier will be paid at the end of the permissible delay in settling account (trade credit).

In addition, the following notations are used throughout this paper:

\section{Decision Variables}

$F \quad=$ The fraction of replenishment cycle in which there is inventory

$T=$ The length of replenishment cycle

$p_{1} \quad=$ The selling price for the units held in stock

$p_{2}=$ The selling price for the units when out of stock

\section{Parameters}

$D\left(p_{i}=\right.$ Demand rate when the selling price is set at $p_{i}$; the demand rate $D\left(p_{i}\right)$ is assumed to be a linear function of $D\left(p_{i}\right)=a_{0}-b_{0} p_{i}$

$\beta=$ The fraction of shortages that will be backlogging

$c=$ The purchasing cost per unit

$A=$ Fixed cost to place and receive an order (ordering cost)

$h=$ The holding cost per unit per unit time excluding interest charges

$s \quad=$ The shortage cost per unit per unit time $g \quad=\quad$ The unit cost of lost sales

$M=$ The retailer's trade credit period offered by supplier in years

$I_{e}=$ The interest that can be earned per unit per unit time

$I_{c} \quad=$ The interest charges per unit per unit time

This section develops three models. Our objective function is to determine the maximum net profit by generating the optimal solutions (decision variables). Then, the net profit can be calculated by considering the following elements:

1. Sales Revenue

$$
\begin{aligned}
& p_{1}\left(a_{0}-b_{0} p_{1}\right) F \\
& +\beta p_{2}\left(a_{0}-b_{0} p_{2}\right)(1-F)
\end{aligned}
$$

2. Purchasing Cost

$$
\begin{aligned}
& c\left(a_{0}-b_{0} p_{1}\right) F \\
& +c \beta\left(a_{0}-b_{0} p_{2}\right)(1-F)
\end{aligned}
$$

3. Ordering Cost

$$
\frac{A}{T}
$$

4. Inventory Holding Cost

$$
\frac{h\left(a_{0}-b_{0} p_{1}\right)}{2} F^{2} T
$$

5. Shortage Cost

$$
\frac{s \beta\left(a_{0}-b_{0} p_{2}\right)}{2}(1-F)^{2} T
$$

6. Lost Sale Cost

$$
g\left(a_{0}-b_{0} p_{2}\right)(1-\beta)(1-F)^{2} T
$$

Regarding interest earned and interest charged, we have the following two possible cases based on the values of $F T, T$, and $M$. Both cases are depicted graphically in figure 1 and 2.

\section{Interest Earned}

When there are some units are sold during the permissible delay in settling account, the retailer can be got the interest earned. For all cases above, at the beginning of the cycle, there is a backordered quantity as $\beta\left(a_{0}-b_{0} p_{2}\right)(1-F) T$. That quantity also can be used to get the interest.

$F T<M<T$

Case I: $M \leq F T<T$, as shown in Figure 1

$$
\frac{1}{T}\left[\begin{array}{l}
\beta\left(a_{0}-b_{0} p_{2}\right)(1-F) T p_{2} M I_{e} \\
+\frac{\left(a_{0}-b_{0} p_{1}\right) M M}{2} p_{1} I_{e}
\end{array}\right]
$$

Case 2: $F T<M<T$, as shown in Figure 2

$$
\begin{aligned}
& \beta\left(a_{0}-b_{0} p_{2}\right)(1-F) p_{2} M I_{e} \\
& +\frac{\left(a_{0}-b_{0} p_{1}\right) F^{2} T}{2} p_{1} I_{e} \\
& +\left(a_{0}-b_{0} p_{1}\right) F(M-F T) p_{1} I_{e}
\end{aligned}
$$




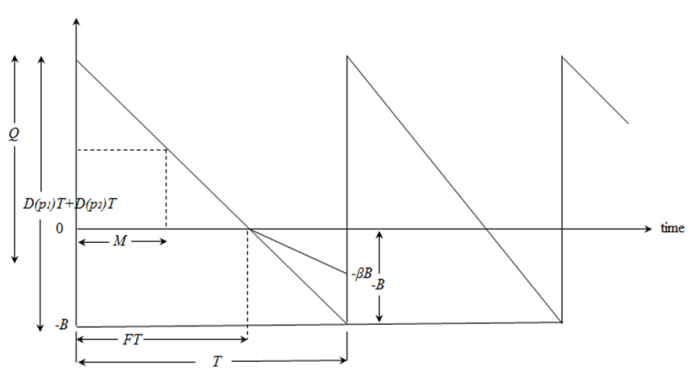

Figure 1 Inventory Diagram for Case

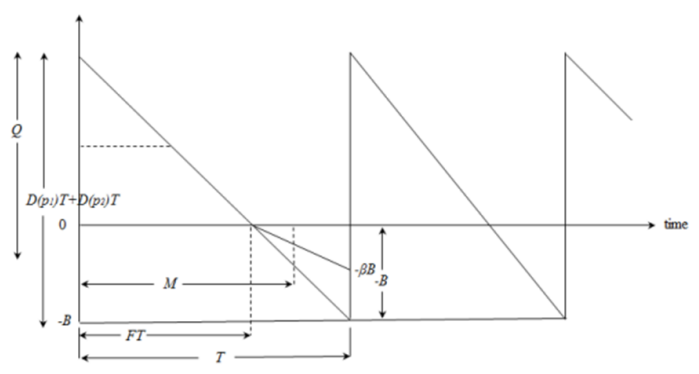

Figure 2 Inventory Diagram for Case

8. Interest Charged

If there are the unit items in stock but the permissible delay in settling account is over, there will be an interest charged per unit for unit item that still in stock.

Case I : $M \leq F T<T$, as shown in Figure 1

$$
\frac{\left(a_{0}-b_{0} p_{1}\right)(F T-M)^{2} c I_{c}}{2 T}
$$

Case 2: $F T<M<T$, as shown in Figure 2

As there is no unit item in stock when the permissible delay in settling account is over, so, the retailer must not be paid the interest charged.

As a result, the total annual profit for each case is given. To make a simple equation, net profit that represents Case 1 will be denoted as $\Pi_{1}$.

Then

$$
\begin{aligned}
& \prod_{1}\left(p_{1}, p_{2}, T, F\right)= \\
& p_{1}\left(a_{0}-b_{0} p_{1}\right) F \\
& +\beta p_{2}\left(a_{0}-b_{0} p_{2}\right)(1-F) \\
& -\left[\begin{array}{l}
c\left(a_{0}-b_{0} p_{1}\right) F \\
+c \beta\left(a_{0}-b_{0} p_{2}\right)(1-F)+\frac{A}{T}+ \\
\frac{h\left(a_{0}-b_{0} p_{1}\right)}{2} F^{2} T \\
+\frac{s \beta\left(a_{0}-b_{0} p_{2}\right)}{2}(1-F)^{2} T+ \\
g\left(a_{0}-b_{0} p_{2}\right)(1-\beta)(1-F)^{2} T
\end{array}\right]
\end{aligned}
$$

$$
\begin{aligned}
& +\frac{1}{T}\left[\begin{array}{l}
\beta\left(a_{0}-b_{0} p_{2}\right)(1-F) T p_{2} M I_{e} \\
+\frac{\left(a_{0}-b_{0} p_{1}\right) M M}{2} p_{1} I_{e}
\end{array}\right. \\
& -\frac{\left(a_{0}-b_{0} p_{1}\right)(F T-M)^{2} c I_{c}}{2 T}
\end{aligned} .
$$

In other hand, net profit that represents Case 2 will be denoted as $\Pi_{2}$. Then

$$
\begin{aligned}
& \Pi_{2}\left(p_{1}, p_{2}, T, F\right)= \\
& p_{1}\left(a_{0}-b_{0} p_{1}\right) F \\
& +\beta p_{2}\left(a_{0}-b_{0} p_{2}\right)(1-F) \\
& {\left[\begin{array}{l}
c\left(a_{0}-b_{0} p_{1}\right) F \\
+c \beta\left(a_{0}-b_{0} p_{2}\right)(1-F)+\frac{A}{T}+
\end{array}\right.} \\
& -\frac{h\left(a_{0}-b_{0} p_{1}\right)}{2} F^{2} T \\
& {\left[\begin{array}{l}
+\frac{s \beta\left(a_{0}-b_{0} p_{2}\right)}{2}(1-F)^{2} T \\
+g\left(a_{0}-b_{0} p_{2}\right)(1-\beta)(1-F)^{2} T
\end{array}\right]} \\
& +\beta\left(a_{0}-b_{0} p_{2}\right)(1-F) p_{2} M I_{e} \\
& +\frac{\left(a_{0}-b_{0} p_{1}\right) F^{2} T}{2} p_{1} I_{e} \\
& +\left(a_{0}-b_{0} p_{1}\right) F(M-F T) p_{1} I_{e}-0
\end{aligned}
$$

Our objective here is to maximize net profit while determining the optimal solution for some decision variables. As noted in Chapter 3, there are four decision variables that may be employed in developing our model. They are $p_{1}, p_{2}, T$, and $F$. To find the optimal solution, say $\left(p_{1}{ }^{*}, p_{2}{ }^{*}, T^{*}, F^{*}\right)$, the following procedure is taken.

Therefore, we propose a solution procedure with considering two different possibilities, which may occur based on different situations with respect to $M, F T$ and $T$.

Case 1. Let $M \leq F T<T$

To obtain the optimal selling price for in-stock period $\left(p_{1}{ }^{*}\right)$, taking the first derivative with respect to $p_{1}$ and setting the result to be zero, thus, we get

$$
p_{1}{ }^{*}=\frac{\left[\begin{array}{l}
2 F T a_{0}+M^{2} I_{e} a_{0}+2 c F T b_{0} \\
+F^{2} h T^{2} b_{0}+c M^{2} I_{c} b_{0} \\
-2 c F T M I_{c} b_{0}+c F^{2} T^{2} I_{c} b_{0}
\end{array}\right]}{2\left(2 F T+M^{2} I_{e}\right) b_{0}}
$$


Likewise, we obtain the first-order condition for $\Pi_{1}\left(p_{1}, p_{2}, T, F\right)$ with respect to $p_{2}$ and setting the result to be zero, then

$$
p_{2}{ }^{*}=\frac{\left[\begin{array}{l}
2 \beta a_{0}+2 M \beta I_{e} a_{0}+2 g T b_{0} \\
-2 F g T b_{0}+2 c \beta b_{0}-2 g T \beta b_{0} \\
+2 F g T \beta b_{0}+s T \beta b_{0}-F s T \beta b_{0}
\end{array}\right]}{4 \beta\left(1+M I_{e}\right) b_{0}}
$$

Using the above equation, we can obtain the optimal selling price for in-stock and out-stock period. Next, substituting (13) and (14) into $\Pi_{1}\left(p_{1}, p_{2}, T, F\right)$ from (11) yields $\Pi_{1}(T, F)$ This represents the maximal net profit for each value of $T, F$.

\section{Case 2. Let $F T<M<T$}

From (12), taking derivative with respect to $p_{1}$ and setting it equal to 0 gives:

$$
p_{1}^{*}=\frac{\left[\begin{array}{l}
2 a_{0}+2 M I_{e} a_{0}-F T I_{e} a_{0} \\
+2 c b_{0}+F h T b_{0}
\end{array}\right]}{2\left(2+2 M I_{e}-F T I_{e}\right) b_{0}}
$$

Similarly, the optimal value of $p_{2}$ which maximizes $\partial \prod_{2}\left(p_{1}, p_{2}, T, F\right)$ can be generated by taking the first derivative of (12) with respect to $p_{2}$ and setting it equal to 0 , we get

$$
p_{2}^{*}=\frac{\left[\begin{array}{l}
2 \beta a_{0}+2 M \beta I_{e} a_{0}+2 g T b_{1} \\
-2 F g T b_{0}+2 c \beta b_{0}-2 g T_{1} \\
+2 F g T \beta b_{0}+s T \beta b_{0}-F s^{\prime}
\end{array}\right)}{4 \beta\left(1+M I_{e}\right) b_{0}}(16
$$

Because of the net profit function, denoted by $\Pi_{2}\left(p_{1}, p_{2}, T, F\right)$, is concave in $p_{1}$ and $p_{2}$. Thus, there exists a unique value of them. These of equations, (15) and (16), represents the equation to obtain the optimal selling price for in-stock period and the optimal selling price for out-stock period.

To determine the optimal value of $T$ and $F$, substitute the equation (15) and (16) into $\prod_{2}\left(p_{1}, p_{2}, T, F\right)$ from (12), we have $\prod_{2}(T, F)$ Right now we only have two decision variables that must be solved to get the maximum value of $\prod_{2}(T, F)$.

Next, we need to check the second order condition for concavity. Taking the second derivative of (11) and the following conditions should be contented:

$$
\frac{\partial^{2} \Pi_{1}\left(p_{1}, p_{2}, T, F\right)}{\partial T^{2}}=
$$

$$
\begin{aligned}
& -\frac{2 A}{T^{3}}-\frac{c F^{2} I_{c}\left(a_{0}-b_{0} p_{1}\right)}{T} \\
& +\frac{2 c F(-M+F T) I_{c}\left(a_{0}-b_{0} p_{1}\right)}{T^{2}} \\
& -\frac{c(-M+F T)^{2} I_{c}\left(a_{0}-b_{0} p_{1}\right)}{T^{3}} \\
& +\frac{M^{2} I_{e} p_{1}\left(a_{0}-b_{0} p_{1}\right)}{T^{3}}
\end{aligned}
$$

And

$$
\begin{aligned}
& \frac{\partial^{2} \Pi_{1}\left(p_{1}, p_{2}, T, F\right)}{\partial F^{2}}= \\
& -h T\left(a_{0}-b_{0} p_{1}\right)-c T I_{c}\left(a_{0}-b_{0} p_{1}\right) \\
& -2 g T(1-\beta)\left(a_{0}-b_{0} p_{2}\right) \\
& -s T \beta\left(a_{0}-b_{0} p_{2}\right)
\end{aligned}
$$

If the optimal value of $T\left(T^{*}\right)$ and $F\left(F^{*}\right)$ met the condition $F^{*} T^{*}<M<T^{*}$, then use equation (12) to check the second order condition. The sufficient conditions are

$$
\begin{aligned}
& \frac{\partial^{2} \Pi_{2}\left(p_{1}, p_{2}, T, F\right)}{\partial T^{2}}= \\
& -\frac{2 A}{T^{3}} \\
& \text { And } \\
& \frac{\partial^{2} \Pi_{2}\left(p_{1}, p_{2}, T, F\right)}{\partial F^{2}}= \\
& -h T\left(a_{0}-b_{0} p_{1}\right)-T I_{e} p_{1}\left(a_{0}-b_{0} p_{1}\right) \\
& -2 g T(1-\beta)\left(a_{0}-b_{0} p_{2}\right) \\
& -s T \beta\left(a_{0}-b_{0} p_{2}\right)
\end{aligned}
$$

\subsection{Algorithm}

Based on the previous study, we generate the following solution algorithm to determine an optimal solution for the approximate model, they are: $p_{1}{ }^{*}, p_{2}{ }^{*}, T^{*}$, and $F^{*}$.

For Case 1

Step 1.1

Determine $\quad T^{\alpha}$ and $F^{\alpha}$ by solving $\frac{\partial \prod_{1}(T, F)}{\partial T}=0$ and $\frac{\partial \prod_{1}(T, F)}{\partial F}=0$

Step 1.2

If there exist $T^{\alpha}$ and $F^{\alpha}$ such that $M \leq T^{\alpha} * F^{\alpha}$, then, $T^{\alpha}$ and $F^{\alpha}$ satisfies the second order condition for concavity in where equation (17) and (18) should be less than zero $(<0)$; otherwise, we set $\Pi_{1}\left(p_{1}{ }^{\alpha}, p_{2}{ }^{\alpha}, T^{\alpha}, F^{\alpha}\right)=-\infty$

Step 1.3

Determine $p_{1}{ }^{\alpha}, p_{2}{ }^{\alpha}$ by substituting the optimal value of $T^{\alpha}$ and $F^{\alpha}$ into equations 
Puspita, dkk., Two-Phase Pricing and Ordering Decisions under Trade Credit

(13) and (14). Then calculate the net profit function, $\Pi_{1}\left({p_{1}}^{\alpha},{p_{2}}^{\alpha}, T^{\alpha}, F^{\alpha}\right)$, by (11).

For Case 2

Step 2.1

Determine $\quad T^{\beta}$ and $F^{\beta}$ by solving $\frac{\partial \prod_{2}(T, F)}{\partial T}=0$ and $\frac{\partial \prod_{2}(T, F)}{\partial F}=0$

Step 2.2

If there exist $T^{\beta}$ and $F^{\beta}$ such that $T^{\beta} * F^{\beta}<M$, then, $T^{\beta}$ and $F^{\beta}$ satisfies the second order condition for concavity in where equation (19) and (20) should be less than zero $(<0)$; otherwise, we set $\Pi_{2}\left(p_{1}{ }^{\beta}, p_{2}{ }^{\beta}, T^{\beta}, F^{\beta}\right)=-\infty$

Step 2.3

Determine $p_{1}{ }^{\beta}, p_{2}{ }^{\beta}$ by substituting the optimal value of $T^{\beta}$ and $F^{\beta}$ into equations (15) and (16). Then calculate the net profit function, $\Pi_{2}\left(p_{1}{ }^{\beta}, p_{2}{ }^{\beta}, T^{\beta}, F^{\beta}\right)$ by (12).

Step 3

Let $\Pi\left(p_{1}{ }^{*}, p_{2}{ }^{*}, T^{*}, F^{*}\right)=$

$\operatorname{Max}\left\{\Pi_{1}\left(p_{1}{ }^{\alpha}, p_{2}{ }^{\alpha}, T^{\alpha}, F^{\alpha}\right)\right.$,

$\left.\Pi_{2}\left(p_{1}{ }^{\beta}, p_{2}{ }^{\beta}, T^{\beta}, F^{\beta}\right)\right\}$

To illustrate the result developed in this work, we apply the proposed method to solve the following numerical examples.

Example 1. The values of the parameters are given as follows: $a_{0}=110, b_{0}=5, \beta=0.6$, $c=10, h=2, g=6, s=2, A=50, I_{e}=0.1$, $I_{c}=0.15, M=0.3$.

As mentioned before, in order to obtain the optimal value, say $\left(p_{1}{ }^{*}, p_{2}{ }^{*}, T^{*}, F^{*}\right)$, we have to solve the complex, nonlinear equations. Hence, we use software MATHEMATICA to obtain the optimal solutions $T^{*}=1.1438$ and $F^{*}=0.8915$ this example is indicated as optimal in case 1. Then to determine the both of selling price, substituting the optimal value of $T^{*}$ and $F^{*}$ into equations (13) and (14), the result is given by $p_{1}{ }^{*}=16.6753$ and $p_{2}{ }^{*}=16.1554$. From calculating equation (11), we determine maximize profit function in which $M \leq F^{*} T^{*}<T$ is 94.677 . Using these optimal values of decision variables, we have $Q=29.6867$ that represent the total ordering quantities.
Figure 3 demonstrates the changes of net profit function with respect to $p_{1}$. The optimal total net profit value (94.677) can be obtained at $p_{1}{ }^{*}=16.6753$. It also describes that if the value of $p_{1}>16.6753$ certainly the total net profit will decrease. The larger the value of $p_{2}$, the more the total net profit is. Figure 4 points out that when the value of $p_{2}{ }^{*}=16.1554$, the maximum net profit can also be generated (94.677). Likewise, the decrease of net profit occurs during $p_{2}>16.1554$.

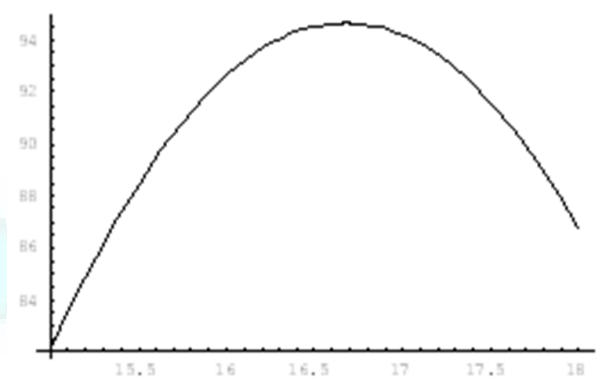

Figure 3 Graphical Description of $\Pi_{1}$ and $p_{1}$

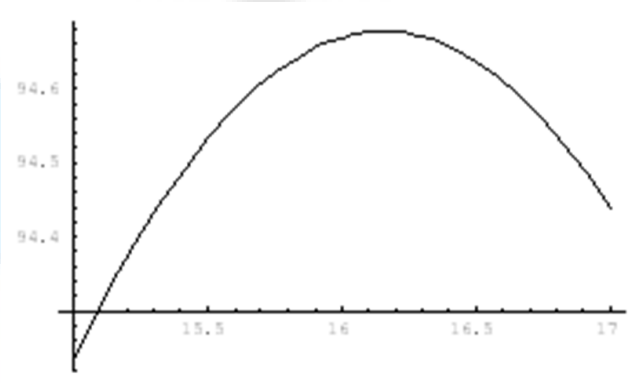

Figure 4 Graphical Description of $\Pi_{1}$ and $p_{2}$

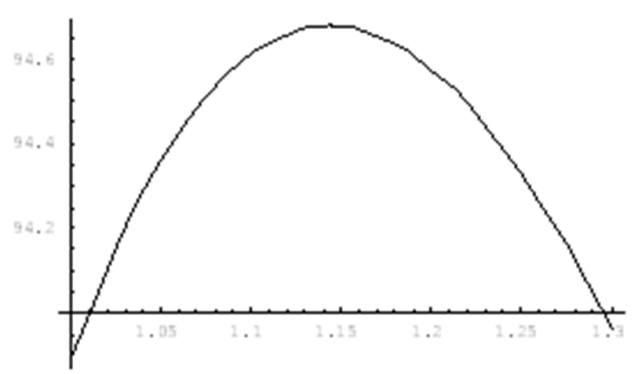

Figure 5 Graphical Description of $\prod_{1}$ and $T$

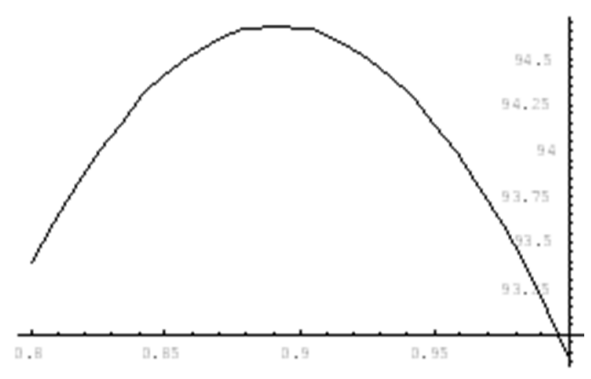

Figure 6 Graphical Description of $\prod_{1}$ and $F$ 
Jurnal Sistem Informasi, Volume 5, Nomor 1, Maret 2014, hlm. 40-50

Meanwhile, Figure 5 and Figure 6 illustrate the optimal cycle time $(T)$ and the optimal percentage of demand filled from stock $(F)$. As designed in these figures, the total net profit is optimum at $T^{*}=1.1438$ and $F^{*}=0.8915$.

Example 2. We assume that the retailer set the both of selling price is similar. In this case, they use one-phase pricing strategy in which $p_{1}=p_{2}$ . We set the data is same as Example 1. And the optimal solution is $p^{*}=16.6366, T^{*}=1.1426$, and $F^{*}=0.89$. Then substituting these optimal values to calculating the net profit, we have 94.5932. Meanwhile, the optimal quantity ordered is 29.293 .

\subsection{Sensitivity Analysis}

In this section, we study the sensitivity of the optimal solution to modify in the values of the different parameters related with the model. In particular, there is only one parameter will be changed while the others remain the same. By developing the algorithm procedure to Example 1 , the changes in the optimal decision values as denoted by $p_{1}{ }^{*}, p_{2}{ }^{*}, T^{*}, F^{*}$ are reported in Table 1-9. All of them are as follows.

Table 1 Sensitivity analysis with respect to $\beta$

\begin{tabular}{|c|c|c|c|c|c|}
\hline$\beta$ & 0.4 & 0.5 & 0.6 & 0.7 & 0.8 \\
\hline$p_{1}^{*}$ & 16.69 & 16.88 & 16.67 & 16.64 & 16.58 \\
\hline$p_{2}{ }^{*}$ & 15.55 & 15.92 & 16.16 & 16.31 & 16.39 \\
\hline$T^{*}$ & 0.966 & 1.053 & 1.144 & 1.240 & 1.347 \\
\hline$F^{*}$ & 1 & 0.982 & 0.892 & 0.789 & 0.671 \\
\hline$\Pi$ & 93.26 & 93.40 & 94.68 & 98.20 & 104.7 \\
\hline$Q$ & 28 & 28 & 29 & 31 & 34 \\
\hline \multicolumn{6}{|c|}{ Table 2 Sensitivity analysis with respect to $c$} \\
\hline$c$ & 8 & 9 & 10 & 11 & 12 \\
\hline$p_{1}^{*}$ & 15.61 & 16.14 & 16.68 & 17.21 & 17.57 \\
\hline$p_{2}{ }^{\bullet}$ & 14.91 & 15.53 & 16.16 & 16.79 & 17.43 \\
\hline$T^{*}$ & 0.995 & 1.069 & 1.144 & 1.224 & 1.313 \\
\hline$F^{*}$ & 0.987 & 0.937 & 0.892 & 0.850 & 0.811 \\
\hline$\Pi$ & 154.1 & 122.8 & 94.68 & 69.66 & 47.65 \\
\hline$Q$ & 32 & 31 & 29 & 28 & 27 \\
\hline \multicolumn{6}{|c|}{ Table 3 Sensitivity analysis with respect to $h$} \\
\hline$h$ & 1 & 1.5 & 2 & 2.5 & 3 \\
\hline$p_{1}^{*}$ & 16.54 & 16.61 & 16.68 & 16.73 & 16.79 \\
\hline$p_{2}{ }^{*}$ & 15.96 & 16.06 & 16.16 & 16.24 & 16.31 \\
\hline$T^{*}$ & 1.251 & 1.189 & 1.144 & 1.109 & 1.082 \\
\hline$F^{*}$ & 0.964 & 0.927 & 0.892 & 0.858 & 0.826 \\
\hline$\Pi$ & 108.5 & 101.1 & 94.68 & 88.98 & 83.90 \\
\hline$Q$ & 34 & 31 & 29 & 28 & 26 \\
\hline
\end{tabular}

Table 4 Sensitivity analysis with respect to $g$

\begin{tabular}{cccccc}
\hline$g$ & 4 & $\mathbf{5}$ & 6 & $\mathbf{7}$ & $\mathbf{8}$ \\
\hline$p_{1}{ }^{*}$ & 16.67 & 16.67 & 16.68 & 16.68 & 16.68 \\
$p_{2}{ }^{*}$ & 15.15 & 16.15 & 16.16 & 16.16 & 16.16 \\
$T^{* *}$ & 1.181 & 1.160 & 1.144 & 1.132 & 1.122 \\
$F^{*}$ & 0.860 & 0.878 & 0.892 & 0.903 & 0.912 \\
$\Pi$ & 95.10 & 94.86 & 94.68 & 94.54 & 94.42 \\
$Q$ & 30 & 29 & 29 & 29 & 29 \\
\hline
\end{tabular}

Table 5 Sensitivity analysis with respect to $s$

\begin{tabular}{cccccc}
\hline$s$ & $\mathbf{1}$ & $\mathbf{1 . 5}$ & $\mathbf{2}$ & $\mathbf{2 . 5}$ & $\mathbf{3}$ \\
\hline$p_{\mathbf{1}}{ }^{*}$ & 16.67 & 16.67 & 16.68 & 16.68 & 16.68 \\
$p_{2}{ }^{*}$ & 15.15 & 16.15 & 16.16 & 16.16 & 16.16 \\
$T^{* *}$ & 1.155 & 1.149 & 1.144 & 1.139 & 1.134 \\
$F^{*}$ & 0.881 & 0.887 & 0.892 & 0.896 & 0.9 \\
$\Pi$ & 94.81 & 94.74 & 94.68 & 94.62 & 94.57 \\
$Q$ & 30 & 29 & 29 & 29 & 29 \\
\hline
\end{tabular}

Table 6 Sensitivity analysis with respect to $A$

\begin{tabular}{|c|c|c|c|c|c|}
\hline$A$ & 30 & 40 & 50 & 60 & 70 \\
\hline$p_{1}^{*}$ & 16.47 & 16.58 & 16.68 & 16.76 & 16.84 \\
\hline$p_{2}{ }^{*}$ & 15.87 & 16.02 & 16.16 & 16.27 & 16.38 \\
\hline$T^{*}$ & 0.792 & 0.981 & 1.144 & 1.29 & 1.425 \\
\hline$F^{* *}$ & 0.991 & 0.929 & 0.892 & 0.866 & 0.847 \\
\hline$\Pi$ & 115.4 & 104.1 & 94.68 & 86.46 & 79.09 \\
\hline$Q$ & 22 & 26 & 29 & 32 & 35 \\
\hline \multicolumn{6}{|c|}{ Table 7 Sensitivity analysis with respect to $I_{e}$} \\
\hline$I_{e}$ & 0.08 & 0.09 & 0.1 & 0.11 & 0.12 \\
\hline$p_{1}{ }^{*}$ & 16.69 & 16.68 & 16.68 & 16.67 & 16.66 \\
\hline$p_{2}{ }^{*}$ & 16.17 & 16.16 & 16.16 & 16.15 & 16.14 \\
\hline$T^{*}$ & 1.144 & 1.144 & 1.144 & 1.144 & 1.143 \\
\hline$F^{*}$ & 0.897 & 0.894 & 0.891 & 0.888 & 0.886 \\
\hline$\Pi$ & 94.15 & 94.41 & 94.68 & 94.93 & 95.22 \\
\hline$Q$ & 29 & 29 & 29 & 29 & 29 \\
\hline \multicolumn{6}{|c|}{ Table 8 Sensitivity analysis with respect to $I_{\sigma}$} \\
\hline$I_{c}$ & 0.13 & 0.14 & 0.15 & 0.16 & 0.17 \\
\hline$p_{1}^{*}$ & 16.67 & 16.67 & 16.68 & 16.68 & 16.68 \\
\hline$p_{2}{ }^{*}$ & 16.14 & 16.15 & 16.16 & 16.15 & 16.17 \\
\hline$T^{*}$ & 1.166 & 1.155 & 1.144 & 1.134 & 1.124 \\
\hline$F^{*}$ & 0.899 & 0.896 & 0.892 & 0.888 & 0.884 \\
\hline$\Pi$ & 95.92 & 95.29 & 94.68 & 94.08 & 93.51 \\
\hline$Q$ & 30 & 30 & 29 & 29 & 29 \\
\hline
\end{tabular}

Table 9 Sensitivity analysis with respect to $M$

\begin{tabular}{cccccc}
\hline$M$ & $\mathbf{0 . 1}$ & $\mathbf{0 . 2}$ & $\mathbf{0 . 3}$ & $\mathbf{0 . 4}$ & $\mathbf{0 . 5}$ \\
\hline$p_{1}^{*}$ & 16.83 & 16.75 & 16.68 & 16.60 & 16.53 \\
$p_{2}{ }^{*}$ & 16.29 & 16.22 & 16.16 & 16.09 & 16.02 \\
$T^{* *}$ & 1.172 & 1.158 & 1.144 & 1.129 & 1.115 \\
$F^{*}$ & 0.882 & 0.887 & 0.892 & 0.897 & 0.902 \\
$\Pi$ & 86.90 & 90.74 & 94.68 & 98.71 & 102.8 \\
$Q$ & 29 & 29 & 29 & 29 & 29 \\
\hline
\end{tabular}


Puspita, dkk., Two-Phase Pricing and Ordering Decisions under Trade Credit

From Table 1 to Table 9, we can make the following observations:

1. As the fraction of shortages that will be backlogging $(\beta)$ and the retailer's trade credit period $(M)$ increase, the total net profit becomes larger. Thus as $M$ increases, the selling price of the in-stock period is increasing, whereas, the selling price of the out-stock period is decreasing. Then, the length of the replenishment cycle then becomes smaller as the credit period becomes larger and the optimal replenishment number will increase accordingly. In contrast to the previous, due to the increase of $\beta$, the selling price of the in-stock period is decreasing and the selling price of the out-stock period is increasing. Then, the length of the replenishment cycle then becomes larger and the optimal total number of unsatisfied demand that will be back ordered is also increasing similar as the quantity ordered. However, both of two circumstances are yield more the total net profit.

2. As the purchasing cost $(c)$ and the ordering cost $(A)$ increase, the total net profit becomes smaller. Both of the selling prices of the in-stock period are increasing similar as the selling price during out-stock period. But, the length of the replenishment cycle then become larger, it causes the interest charged must be paid more by retailer. As $c$ and $A$ increase, the percentage of demand that will be filled from stock is also decreasing and the optimal backordered demand will increase accordingly. In other hand, as $c$ is increasing, the optimal quantity ordered is decreasing; otherwise when $A$ is increasing, the optimal quantity ordered is increasing.

3. As the holding $\operatorname{cost}(h)$ for the retailer increases, the total net profit becomes smaller. Both of the selling prices are increasing. In other hand, the length of the replenishment cycle then becomes smaller. Therefore, the optimal quantity ordered will decrease.

4. As the interest earned $\left(I_{e}\right)$ is increasing, both of the selling prices are decreasing. Then, the length of the replenishment cycle then becomes smaller. Meanwhile, the net profit is increasing as the internet earned is also increasing.

As the lost sale cost $(g)$, the shortage cost $(s)$, the selling price of the in-stock period is increasing and the selling price of the out-stock period is also increasing. In other hand, the length of the replenishment cycle then becomes small- er. When $g$ and $s$ are increasing, the percentage of unsatisfied demand that will be backordered then becomes larger. Meanwhile, when the interest charged $\left(I_{c}\right)$ is increasing, the percentage of unsatisfied demand that will be backordered then becomes smaller.

\section{CONCLUSION and FURTHER RESEARCH}

\subsection{Management Insight}

In this research, an inventory model for a retailer's two-phase pricing strategy, partial backlogging and lot-sizing problem with pricedependent demand under trade credit financing is presented. This means that the retailer determines the both of selling prices, they are: selling price for in-stock period and selling price for out-stock period, as decision variable. In here, we also consider the length of the replenishment cycle and the percentage of demand filled from stock as decision variable. To determine the optimal solutions, we propose an algorithm procedure as noted in previous chapter while still maximizing the total net profit.

Sensitivity analysis shows that by minimizing the variable cost, such as: purchasing cost per unit item, holding cost per unit item, and ordering cost, the net profit will be optimum. Meanwhile, the alternation of shortage cost is insensitive to change total net profit and ordered quantity. Similar as shortage cost, the lost sale cost, interest earned is also has a bit impact to both of them. In order to obtain more total net profit, when the selling price for out-stock period is greater, the retailer needs to backorder more unsatisfied de-mands. The other hand, if the ordering cost becomes larger, the retailer need to order more quantities. Then, the length of the replenishment cycle then becomes smaller. Therefore, the total net profit will be optimum.

Moreover, we find that this proposed model that considering two-phase pricing strategy is supreme to one-phase pricing strategy for obtaining the maximum profit. From Example 1 and Exam-ple 2, we know that two-phase pricing can generate the profit greater than one-phase pricing. For ordering decisions, when we implement two-phase pricing strategy, we should be order more product from supplier, since the demand rate is increases than the other one.

\subsection{Future Work}

The proposed model can be extended in several ways. For instance, we may consider that in the occurrence of shortage, the percentage of customers who will wait until their demand is 
satisfied decreases as the waiting time increases. In other word, backorder of shortages is time dependent. And further, it would be interesting to set the actual demand is stochastic. It means that we need to forecast how many the demands that must be met. Furthermore, besides a credit period to the retailer, we develop such a policy to the customers. It called as the two-level credit policy.

\section{REFERENCES}

Abad, P.L.: 'Optimal price and order size for a reseller under partial backordering', Computers \& Operations Research, 2001, 28, (1), pp. 53-65

Abad, P.L.: 'Optimal price and order size under partial backordering incorporating shortage, backorder and lost sale costs', International Journal of Production Economics, 2008, 114, (1), pp. 179-186

Banerjee, S., and Sharma, A.: 'Optimal procurement and pricing policies for inventory models with price and time dependent seasonal demand', Mathematical and Computer Modelling, 2010, 51, (5-6), pp. 700714

Chang, H.-C., Ho, C.-H., Ouyang, L.-Y., and $\mathrm{Su}, \mathrm{C} . \mathrm{-H} .:$ 'The optimal pricing and ordering policy for an integrated inventory model when trade credit linked to order quantity', Applied Mathematical Modelling, 2009, 33, (7), pp. 2978-299

Chang, C.-T., Goyal, S.K., and Teng, J.-T.: 'On "An EOQ model for perishable items under stock-dependent selling rate and time-dependent partial backlogging" by Dye and Ouyang', European Journal of Operational Research, 2006, 174, (2), pp. 923-929

Chung, K.-J., and Huang, C.-K.: 'An ordering policy with allowable shortage and permissible delay in payments', Applied Mathematical Modelling, 2009, 33, (5), pp. 25182525

Chung, K.-J., and Lin, S.-D.: 'The inventory model for trade credit in economic ordering policies of deteriorating items in a supply chain system', Applied Mathe-matical Modelling, 2011, 35, (6), pp. 3111-3115

Goyal, S.K.: 'Economic order quantity under conditions of permissible delay in payments', The Journal of the Operational Research Society 1985,36 , pp. 335-338

Hu, W.-t., Kim, S.-L., and Banerjee, A.: 'An inventory model with partial backordering and unit backorder cost linearly increasing with the waiting time', European Journal of
Operational Research, 2009, 197, (2), pp. 581-587

Huang, Y.-F.: 'Economic order quantity under conditionally permissible delay in payments', European Journal of Operati-onal Research, 2007, 176, (2), pp. 911-924

Jaggi, C.K., and Aggarwal, S.P.: 'Credit financing in economic ordering policies of deteriorating items', International Journal of Production Economics, 1994, 34, (2), pp. 151-155

Jamal, A.M.M., Sarker, B. R., Wang, S.,: 'An ordering policy for deteriorating items with allowable shortages and permissible delay in payment', Journal of the Operational Research Society, 1997, 48, (826-833)

Park, K.S.: 'Inventory model with partial backorders', International Journal of Systems Science, 1982, 13, (12), pp. 1313-1317

Pentico, D.W., and Drake, M.J.: 'The deterministic EOQ with partial backordering: A new approach', European Journal of Operational Research, 2009, 194, (1), pp. 102113

Sana, S.S.: 'Optimal selling price and lotsize with time varying deterioration and partial backlogging', Applied Mathematics and Computation, 2010, 217, (1), pp. 185-194

Taleizadeh, A.A., Pentico, D.W., Saeed Jabalameli, M., and Aryanezhad, M.: 'An EOQ model with partial delayed payment and partial backordering', Omega, 2013, 41, (2), pp. 354-368

Taleizadeh, A.A., and Nematollahi, M.: 'An inventory control problem for deteriorating items with back-ordering and financial considerations', Applied Mathematical Modelling, (0)

Taleizadeh, A.A., Pentico, D.W., Aryanezhad, M., and Ghoreyshi, S.M.: 'An economic order quantity model with partial backordering and a special sale price', European Journal of Operational Research, 2012, 221, (3), pp. 571-583

Tsao, Y.C.: 'Two-phase pricing and inventory management for deteriorating and fashion goods under trade credit', Mathematical Methods and Operations Research, 2010, 72, pp. 107-127

Teng, J.-T., Chang, C.-T., and Goyal, S.K.: 'Optimal pricing and ordering policy under permissible delay in payments', International Journal of Production Economics, 2005, 97, (2), pp. 121-129

Toews, C., Pentico, D.W., and Drake, M.J.: 'The deterministic EOQ and EPQ with partial backordering at a rate that is linearly 
Puspita, dkk., Two-Phase Pricing and Ordering Decisions under Trade Credit

dependent on the time to delivery', International Journal of Production Economics, 2011, 131, (2), pp. 643-649

Vijayan, T., and Kumaran, M.: 'Inventory models with a mixture of backorders and lost sales under fuzzy cost', European Journal of Operational Research, 2008, 189, (1), pp. 105-119

Wang, S.-P.: 'An inventory replenishment policy for deteriorating items with shortages and partial backlogging', Compu-ters \&
Operations Research, 2002, 29, (14), pp. 2043-2051

Wee, H.-M.: 'Deteriorating inventory model with quantity discount, pricing and partial backordering', International Journal of Production Economics, 1999, 59, (1-3), pp. 511-518

You, P.-S.: 'Ordering and pricing of service products in an advance sales system with price-dependent demand', European Journal of Operational Research, 2006, 170, (1), pp. $57-71$ 